\title{
ODMOWA PRZYJĘCIA NA POKŁAD STATKU POWIETRZNEGO WEDŁUG PRZEPISÓW ROZPORZĄDZENIA (WE) NR 261/2004
}

\section{WPROWADZENIE}

Często się zdarza, że pasażerowie, którzy posiadają potwierdzoną rezerwację, bez uprzedniego poinformowania przewoźnika, nie stawiają się do odprawy. Celem umożliwienia jak największej liczbie pasażerów dostępności miejsc $\mathrm{w}$ samolocie przewoźnik może potwierdzać rezerwacje ponad liczbę miejsc przewidzianych $\mathrm{w}$ samolocie. W takim wypadku może się okazać, że pasażer pomimo potwierdzonej rezerwacji i ważnego biletu nie zostanie przyjęty na pokład samolotu ${ }^{1}$.

Artykuł dotyczy problematyki odmowy przyjęcia pasażera na pokład samolotu oraz tzw. overbookingu, czyli niewpuszczenia pasażera na pokład z powodu zgłoszenia się do odprawy większej liczby pasażerów niż liczba miejsc w samolocie. Praktyka ta stosowana jest przez większość przewoźników lotniczych odmawiają oni przyjęcia na pokład pasażera pomimo potwierdzonej rezerwacji i ważnego biletu. Bronią się oni w ten sposób przed tzw. no-shows, czyli osobami, które dokonały rezerwacji, lecz nie stawiły się na wybrany lot. Przewoźnicy, dążąc do maksymalnego wykorzystania pokładu samolotu oraz mając na uwadze, że pewna liczba pasażerów się nie pojawi, dokonują rezerwacji większej niż liczba miejsc, ażeby uzupełnić te różnice. Niestety nie można dokładnie przewidzieć liczby no-shows i dlatego też błędna kalkulacja prowadzić może do „,nadrezerwacji”2. Przemysł linii lotniczych charakteryzuje się specyficzną strukturą płatniczą: gdy przewoźnik uruchamia lot, ustala konkretne nakłady pieniężne, a w momencie startu samolotu koszt niesprzedanych miejsc jest stracony bezpowrotnie ${ }^{3}$. W związku z tym problem maksymalizacji wykorzystywania miejsc jest szczególnie ważny dla przewoźników lotniczych, a każde wolne miejsce oznacza utratę dochodu, dlatego też dążą oni do maksymalizacji zysku przez minimalizację pustych miejsc ${ }^{4}$.

\footnotetext{
${ }^{1}$ Art. 22 Ogólnych warunków przewozu Centralwings.

${ }^{2}$ A. Konert, Overbooking $w$ transporcie lotniczym, „Radca Prawny” 2007, nr 4, s. 83.

3 Jak układają się relacje między cenami biletów lotniczych a zyskiem przewoźników zob. S. Gen. Accounting Office, Aviation Competition: Restricting Airline Ticketing Rules Unlikely to Help Consumers, Pub. No. GAO-01-831, at 5 (2001), cyt. w: A. Konert, Odpowiedzialność przewoźnika lotniczego, Warszawa 2010, s. 209.

${ }^{4}$ E. Blanchard, Terminal 250: Federal Regulation of Airline Overbooking, „New York University Law Review” 79, 2004, nr 5, cyt. w: A. Konert, Odpowiedzialność przewoźnika lotniczego, ibidem.
} 
Przewoźnik lotniczy może odmówić pasażerowi wejścia na pokład nie tylko z powodu braku miejsca (overbooking), lecz także na przykład w sytuacji, gdy stawił się on na lot po czasie wskazanym przez przewoźnika w ogólnych warunkach przewozu. Może to nastąpić z przyczyn leżących po stronie przewoźnika (np. na skutek opóźnienia pierwszego lotu) albo od niego niezależnych (np. pasażer zaspał, duży ruch na drodze na lotnisko lub przedłużająca się kontrola na lotnisku). Innym powodem niewpuszczenia pasażera na pokład moga być względy bezpieczeństwa (np. jest on agresywny lub pod wpływem alkoholu lub istnieje podejrzenie, że jest terrorystą). Wobec powyższych możliwych sytuacji powstaje pytanie: Czy według przepisów rozporządzenia (WE) nr 261/2004 z 11 lutego 2004 r. ustanawiającego wspólne zasady odszkodowania i pomocy dla pasażerów w wypadku odmowy przyjęcia na pokład albo odwołania lub dużego opóźnienia lotów, uchylającego rozporządzenie $\mathrm{nr} 295 / 91^{5}$ pasażerowi przysługują roszczenia tylko w sytuacji odmowy wejścia na pokład z powodu overbookingu, czy też mogą wchodzić w grę inne powody?

Problematyka ta zostanie omówiona na podstawie dwóch rozbieżnych wyroków: wyroku Wojewódzkiego Sądu Administracyjnego w Warszawie z 11 lipca 2007 r. ${ }^{6}$ oraz wyroku Trybunału Sprawiedliwości Unii Europejskiej (trzecia izba) z 4 października 2012 r. w sprawie C-321/11 Germán Rodríguez Cachafeiro, María de los Reyes Martínez-Reboredo Varela-Villamor przeciwko Iberia, Líneas Aéreas de España $S A^{7}$, wydanych na podstawie rozporządzenia $261 / 2004$.

\section{ODPOWIEDZIALNOŚ́ PRZEWOŹNIKA LOTNICZEGO ZA ODMOWE PRZYJECCIA NA POKŁAD PASAŻERA WEDŁUG PRZEPISÓW ROZPORZĄDZENIA (WE) NR 261/2004}

$\mathrm{Na}$ początku lat osiemdziesiątych ubiegłego wieku, podczas prac nad rozwojem wspólnotowej polityki transportu lotniczego zwrócono uwagę na konieczność uregulowania kwestii overbookingu ${ }^{8}$. Ponieważ praktyka przewoźników lotniczych w dziedzinie odszkodowań za odmowę przyjęcia na pokład znacznie się różniła, należało stworzyć minimalne wspólne standardy, które powinny zapewnić utrzymanie jakości usług przewoźników w kontekście wzrostu konkurencji. W 1990 r. Komisja Europejska przedstawiła propozycję rozporządzenia przyznającego pasażerom, którym odmówiono wejścia na pokład z powodu overbookingu, prawo do odszkodowania na zasadach ustalonych w rozporządzeniu, a 4 lutego $1991 \mathrm{r}$. Rada, przyjmując propozycję Komisji, uchwaliła rozporządzenie nr 295/91 ustanawiające wspólne zasady

${ }^{5}$ Dz. Urz. WE L 46 z 17 lutego 2004 r. (dalej jako: rozporządzenie nr 261/2004).

${ }^{6}$ VI SA/Wa $648 / 07$.

${ }^{7}$ Dz. Urz. C 232 z 6 sierpnia 2011 r.

${ }^{8}$ Parlament européen, „Resolution sur les restrictions de la concurrence dans le domaine des transports aériens”, JO nr C 291, 10.11.80, s. 60; Parlament européen, „,Resolution sur le mermorandum de la Commission des Communautes européenes relatif a la contribution de la C.E. au développement des services de transport aérien”, JO nr C 291, 10.11.80, s. 65; Aviation civile. Mermorandum nr 2, „Etat d'avancemente des travaux en vue de développement d'une politique commune du tranporte aérien", COM (84) 72 Final, Bruselas, 15.03.84. 
systemu odszkodowań dla pasażerów, którym odmówiono przyjęcia na pokład w regularnych przewozach lotniczych. Ponieważ wciąż wzrastała liczba skarg pasażerów nie tylko na odmowę przyjęcia na pokład, lecz także na odwołanie czy też opóźnienie lotu oraz w celu podniesienia standardów ochrony zarówno przez wzmocnienie praw pasażerów, jak i zapewnienie przewoźnikom lotniczym działalności w ujednoliconych warunkach na zliberalizowanym rynku ${ }^{9}$, Parlament Europejski i Rada, uwzględniając wniosek Komisji ${ }^{10}$, wydały rozporządzenie (WE) nr 261/2004 z 11 lutego 2004 r. ustanawiające wspólne zasady odszkodowania i pomocy dla pasażerów w wypadku odmowy przyjęcia na pokład albo odwołania lub dużego opóźnienia lotów, uchylające rozporządzenie nr 295/91. Rozporządzenie ma zastosowanie do:

- pasażerów odlatujących z lotniska znajdującego się na terytorium państwa członkowskiego;

- pasażerów odlatujących z lotniska znajdującego się w kraju trzecim i lądujących na lotnisku w państwie członkowskim, jeżeli przewoźnik jest przewoźnikiem wspólnotowym ${ }^{11}$ (chyba że otrzymali oni korzyść lub odszkodowanie oraz udzielono im opieki w tym kraju trzecim) ${ }^{12}$.

W wypadku odmowy przyjęcia na pokład przewoźnik zobowiązany jest znaleźć ochotników, którzy dobrowolnie zgodzą się na rezygnację z lotu w zamian za korzyści uzgodnione między pasażerem a przewoźnikiem. Ten wymóg poszukiwania ochotników bez wątpienia daje więcej elastyczności zarówno pasażerom, jak i samym przewoźnikom ${ }^{13}$. Gdy jednak liczba ochotników jest niewystarczająca, przewoźnik może odmówić przyjęcia na pokład innych pasażerów, nawet wbrew ich woli. Może to jednak nastąpić pod warunkiem wypłaty odszkodowania. Artykuł 4 ust. 3 rozporządzenia przewiduje, że w sytuacji odmowy przyjęcia na pokład pasażerów wbrew ich woli, przysługują im następujące prawa:

a) prawo żądania zwrotu ceny biletu w ciagu 7 dni lub prawo do żądania innego lotu do miejsca przeznaczenia (wraz z zmiana planu podróży, na porównywalnych warunkach $\mathrm{w}$ najwcześniejszym możliwym terminie). Rozporządzenie nie precyzuje, czy przewoźnicy powinni przekazywać pasażerów innym przewoźnikom ani czy mogą oferować im transport naziemny. Użycie wyrażenia „na porównywalnych warunkach” może powodować wątpliwości interpretacyjne. Większość tanich linii lotniczych, w przeciwieństwie do bogatszych przewoźników, nie zawarła porozumień, które umożliwiaja w razie konieczności zmianę planu podróży z pomocą innych przewoźników po niższej cenie na zasadach wzajemności. Wobec tego przewoźnicy low-cost preferuja zwrot kosztów podróży lub w ostateczności pasażerowie są zmuszeni oczekiwać kilka lub kilkanaście godzin na następny lot obsługiwany przez tych przewoźników ${ }^{14}$;

\footnotetext{
${ }^{9}$ Preambuła rozporządzenia $\mathrm{nr} 261 / 2004$.

${ }^{10}$ COM (2001) 784 final oraz DOCE C 103 E/225 z 30.04.2002.

${ }^{11}$ Przewoźnik wspólnotowy - oznacza przewoźnika lotniczego z ważną licencja na prowadzenie działalności wydaną przez państwo członkowskie zgodnie z przepisami rozporządzenia Rady nr 2407/92 z 1992 r. w sprawie wydawania licencji przewoźnikom lotniczym (art. 2 pkt c).

${ }^{12}$ Art. 3 rozporządzenia.

${ }^{13}$ Zob. A. Konert, Odpowiedzialność..., s. 228.

${ }^{14}$ Ibidem, s. 229.
} 
b) prawo do posiłków i napojów w ilościach odpowiednich do czasu oczekiwania;

c) prawo do zakwaterowania w razie konieczności (np. w razie pobytu przez jedną lub więcej nocy);

d) prawo do transportu z lotniska do miejsca noclegu;

e) prawo do dwóch rozmów telefonicznych, wysłania dwóch faksów lub dwóch e-maili;

f) prawo do niezwłocznej wypłaty odszkodowania w wysokości:

- 250 euro: lot do $1500 \mathrm{~km}$;

- 400 euro: lot od 1500 do $3500 \mathrm{~km}$;

- 600 euro: lot powyżej $3500 \mathrm{~km}$.

Natomiast gdy przewoźnik oferuje alternatywny lot, którym pasażer przybyłby do miejsca przeznaczenia nie później niż 2 godziny (dla lotów do $1500 \mathrm{~km}$ ), 3 godziny (dla lotów od 1500 do $3500 \mathrm{~km}$ ) lub 4 godziny (dla lotów ponad $3500 \mathrm{~km}$ ) od planowanego pierwotnie czasu przylotu, odszkodowanie może zostać zmniejszone o $50 \%$.

Według art. 2 lit. j „odmowa przyjęcia na pokład” oznacza odmowę przewozu pasażerów danym lotem, pomimo że stawili się oni do wejścia na pokład zgodnie z warunkami ustanowionymi w rozporządzeniu, chyba że odmowa przyjęcia na pokład jest racjonalnie uzasadniona, w szczególności przyczynami związanymi ze zdrowiem, wymogami bezpieczeństwa lub niewłaściwymi dokumentami podróżnymi.

Rozporządzenie zawiera ponadto obowiązek informowania pasażerów o przysługujących im prawach i jednocześnie wprowadza taką informację: ,jeśli odmówiono Państwu przyjęcia na pokład lub Państwa lot został odwołany lub opóźniony co najmniej o dwie godziny, możecie Państwo poprosić obsługę na stanowisku odpraw lub w punkcie przyjęć pasażerów na pokład samolotu o tekst określający przysługujące Państwu prawa, w szczególności w odniesieniu do odszkodowania i należnej Państwu pomocy". Rozporządzenie nie narusza praw pasażerów do dochodzenia dalszego odszkodowania (art. 12).

\section{ANALIZA ORZECZEŃ DOTYCZACYCH ODMOWY WPUSZCZENIA NA POKŁAD PASAŻERÓW}

Pierwszy z analizowanych wyroków został wydany na podstawie następującego stanu faktycznego. Pasażerka K. L. miała wykupiony bilet na rejs W.-P.-H.-E. u przewoźnika lotniczego A. S.A. Pasażerka punktualnie stawiła się do odprawy pasażerów w W. na rejs i została odprawiona do H. Samolot wyleciał punktualnie $\mathrm{z}$ W. i wylądował $\mathrm{w}$ P. zgodnie $\mathrm{z}$ rozkładem lotu. W P. jednak pasażerka ta nie została przyjęta na pokład samolotu A. na rejs do H., planowany na godzinę 10.20 , którym miała kontynuować dalszą podróż do E. Jako przyczynę odmowy przyjęcia na pokład podano fakt, że pasażerka K. L. nie stawiła się o wskazanym czasie w punkcie przyjęcia pasażerów samolotu z powodu wydłużonego czasu oczekiwania na kontrolę prześwietlenia bagażu podręcznego. Pasażerka zwróciła się ze skarga do Prezesa Urzędu Lotnictwa 
Cywilnego na postępowanie przewoźnika A. S.A., zarzucając mu brak jakiejkolwiek opieki oraz pomocy na lotnisku w P., w tym w szczególności niezapewnienie bezpłatnego noclegu w P., skoro musiała czekać na następny rejs do $\mathrm{H}$. Prezes stwierdził naruszenie przez przewoźnika lotniczego A. S.A. - Oddział w Polsce z siedzibą w W. postanowień art. 7 ust. 1 lit. c) w zw. z art. 4 ust. 3 rozporządzenia (WE) nr 261/2004 Parlamentu Europejskiego i Rady z 11 lutego 2004 r. ustanawiającego wspólne zasady odszkodowania i pomocy dla pasażerów w wypadku odmowy przyjęcia na pokład albo odwołania lub dużego opóźnienia lotów, uchylającego rozporządzenie (EWG) nr 295/91, polegające na niewypłaceniu pasażerce K. L. odszkodowania w wysokości 600 euro w związku z odmową przyjęcia na pokład na rejs nr z P. do H. Przewoźnik lotniczy zwrócił się do Wojewódzkiego Sądu Administracyjnego w Warszawie ze skargą na decyzję Prezesa Urzędu Lotnictwa Cywilnego ${ }^{15}$. Wojewódzki Sąd Administracyjny w Warszawie orzekł, że ,nie można z przepisu art. 4 ust. 3 rozporządzenia (WE) nr 261/2004 Parlamentu Europejskiego i Rady z dnia 11 lutego $2004 \mathrm{r}$. ustanawiajacego wspólne zasady odszkodowania i pomocy dla pasażerów w wypadku odmowy przyjęcia na pokład albo odwołania lub dużego opóźnienia lotów, uchylające rozporządzenie (EWG) nr 295/91 (Dz.Urz.WE L 46 z dnia 17 lutego 2004 r.) tworzyć samoistnej normy prawnej, która w oderwaniu od brzmienia przepisów ust. 1 i ust. 2 tego artykułu, a także w sprzeczności do dyspozycji postanowień Preambuły do tego rozporządzenia, stanowić ma rzekomą podstawę do odszkodowania w każdej sytuacji odmowy przyjęcia pasażera na pokład samolotu, a więc również w wypadkach, gdy nie występuje zawyżona liczba rezerwacji na dany lot (overbooking)" ${ }^{16}$.

Analizowana sprawa dotyczy więc odpowiedzi na pytanie, czy rozporządzenie nr 261/2004 reguluje kwestie odpowiedzialności przewoźnika (wypłaty zryczałtowanego odszkodowania) jedynie za overbooking, czy też odmowa przyjęcia na pokład, w rozumieniu rozporządzenia, obejmuje także inne sytuacje. Jednoznaczne ustalenie, czy wystapiła sytuacja overbookingu, ma istotne znaczenie, albowiem przesądza o podstawie do ewentualnego zastosowania norm wskazanych w przepisach rozporządzenia. Należy skrytykować de lege lata stanowisko WSA w Warszawie, że rozporządzenie dotyczy jedynie sytuacji overbookingu. W ocenie Sądu przepisy powyższe ewidentnie dotyczą wyłącznie sytuacji, w której zachodzi wypadek zawyżonej liczby rezerwacji na dany lot. Wynika to przede wszystkim z literalnego brzmienia samego przepisu art. 4 ust. 1-3 rozporządzenia $\mathrm{nr} 261 / 2004$ oraz z postanowień preambuły do tego rozporządzenia, ale także $\mathrm{z}$ analizy poprzednio obowiązującego rozporządzenia Rady (EWG) nr 295/91 z 4 lutego 1991 r. ustanawiającego wspólne zasady systemu odszkodowań dla pasażerów, którym odmówiono przyjęcia na pokład w regularnych przewozach lotniczych. Sąd odwołał się więc

${ }^{15}$ Pasażerowie lotniczy mają dwie możliwości dochodzenia roszczeń. Pierwsza możliwość to procedura administracyjna: pasażer składa skargę na decyzję przewoźnika lotniczego do Prezesa Urzędu Lotnictwa Cywilnego, na którą z kolei obie strony mogą wnieść skargę do sądu administracyjnego, jako że decyzja Prezesa ULC jest decyzją administracyjną. Druga możliwość to złożenie pozwu cywilnego w sądzie.

${ }^{16}$ Wyrok Wojewódzkiego Sądu Administracyjnego w Warszawie z 11 lipca 2007 r., VI SA/Wa $648 / 07$. 
przede wszystkim do wykładni językowej, co uczyniłaby większość sądów krajowych w kulturze kontynentalnej (stosując prawo krajowe). Jak słusznie zauważono w doktrynie, Trybunał Sprawiedliwości Unii Europejskiej jest „luźniej” związany literą prawa ${ }^{17}$. Przyjęcie przez WSA w Warszawie bezwzględnego pierwszeństwa wykładni językowej przepisów prawa europejskiego nie jest słuszne, dlatego że wiele pojęć na gruncie prawa europejskiego nie ma ustalonego znaczenia (jest to tzw. prawo kompromisu), a ze względu na wielość języków argumentacje językowe stanowić powinny jedynie punkt wyjścia ustaleń derywacyjno-klaryfikacyjnych ${ }^{18} \mathrm{i}$ dawać pierwszeństwo innym zasadom wykładni prawa przy interpretacji przepisów rozporządzeń europejskich.

Zdaniem WSA w Warszawie należy zauważyć, że właśnie w świetle ww. rozporządzenia Rady (EWG) nr 295/91 ustawodawca wspólnotowy uregulował po raz pierwszy kwestię pewnego wspólnego, niemniej bardzo ograniczonego systemu odszkodowań dla pasażerów. $\mathrm{Z}$ przepisu art. 1 tego rozporządzenia wyraźnie wynikało, że dotyczy ono wyłącznie sytuacji, w których pasażerom odmawia się wstępu na pokład na lot regularny o zawyżonej liczbie rezerwacji. Przepisy tego rozporządzenia nie przewidywały odszkodowania ani jakiejkolwiek innej pomocy dla pasażerów w wypadku zarówno odwołania, jak i opóźnienia lotu pasażerskiego - pozostawiały te kwestie poza regulacją tego aktu normatywnego. Ponieważ przepisy te nie regulowały jednak wszystkich uciążliwych sytuacji, będących przyczyną nie tylko niezadowolenia konsumentów, lecz także powodujących wymierne finansowe straty po ich stronie (utracone transakcje, niedoszłe do skutku spotkania itp.), Wspólnota Europejska postanowiła wprowadzić nową regulację prawna, rozszerzającą dotychczasowy system ochrony praw pasażerów transportu lotniczego o nowe dwie sytuacje, a mianowicie: odwołań i opóźnień lotów.

Nie można zgodzić się ze stanowiskiem WSA w Warszawie z kilku powodów. Po pierwsze, samo rozporządzenie zawiera definicję „odmowy przyjęcia na pokład". Jest to mianowicie odmowa przewozu pasażerów danym lotem, pomimo że stawili się oni do wejścia na pokład zgodnie $\mathrm{z}$ warunkami ustanowionymi w rozporządzeniu (posiadali potwierdzoną rezerwację oraz stawili się nie później niż 45 minut przed ogłoszoną godziną odlotu), chyba że odmowa przyjęcia na pokład jest racjonalnie uzasadniona, w szczególności przyczynami związanymi ze zdrowiem pasażera, wymogami bezpieczeństwa lub niewłaściwymi dokumentami podróżnymi. Zatem sam ustawodawca nie zawęził definicji „odmowy przyjęcia na pokład” wyłącznie do overbookingu. Po drugie, nie należy zapominać o celu, jaki przyświecał ustawodawcy - podnieść standardy ochrony pasażerów przez wzmocnienie ich praw (preambuła pkt 4). Niepożądana jest więc sytuacja, w której to pasażerowie zostaną całkowicie pozbawieni swoich praw. Według wykładni systemowej nie należy interpretować przepisów w sposób prowadzacy do luk prawnych. Ograniczenie się jedynie do sytuacji overbookingu oznaczałoby pozostawienie pasażerów bez prawa do odszko-

\footnotetext{
${ }^{17}$ A. Kalisz, Wyktadnia $i$ stosowanie prawa wspólnotowego, Warszawa 2007, s. 152 i n.; eadem, Interpretacja prawa Unii Europejskiej, w: A. Wróbel (red.), Stosowanie prawa Unii Europejskiej przez sady, t. 1, Warszawa 2010, s. 329 i n.

18 A. Kalisz, Wyktadnia..., s. 155.
} 
dowania za inne przyczyny odmowy przyjęcia na pokład wbrew ich woli. Brak bowiem również tego typu regulacji na szczeblu międzynarodowym. I wreszcie, przy interpretacji tych przepisów należy brać pod uwagę normy moralne, zasady sprawiedliwości, słuszności, konsekwencje społeczne i ekonomiczne. W tym wypadku należałoby dać pierwszeństwo pasażerom jako słabszej stronie umowy o przewóz. Wobec powyższego uważam, że przepis art. 4 ust. 3 rozporządzenia (WE) $\mathrm{nr}$ 261/2004 nie dotyczy tylko overbookingu, ale również innych sytuacji, gdy pasażer nie zostanie wpuszczony na pokład samolotu.

Drugi analizowany wyrok został wydany w sprawie C-321/11 Germán Rodríguez Cachafeiro i María de los Reyes Martínez-Reboredo Varela-Villamor przeciwko Iberia, Líneas Aéreas de España SA. Trybunał Sprawiedliwości Unii Europejskiej orzekł w nim, że „Artykuł 2 lit. j) rozporządzenia (WE) nr 261/2004 Parlamentu Europejskiego i Rady z dnia 11 lutego 2004 r. ustanawiającego wspólne zasady odszkodowania i pomocy dla pasażerów w wypadku odmowy przyjęcia na pokład albo odwołania lub dużego opóźnienia lotów, uchylającego rozporządzenie (EWG) nr 295/91, w związku z art. 3 ust. 2 rozporządzenia $\mathrm{nr}$ 261/2004 powinien być interpretowany w ten sposób, że pojęcie »odmowy przyjęcia na pokład « obejmuje sytuację, w której w ramach umowy jednego transportu obejmującego kilka rezerwacji na bezpośrednio następujące po sobie loty, na które odprawa dokonywana jest jednocześnie, przewoźnik lotniczy odmawia przyjęcia na pokład niektórych pasażerów z tego powodu, iż pierwszy lot objęty rezerwacją doznał opóźnienia, za które winę ponosi ów przewoźnik, który błędnie przewidział, że pasażerowie ci nie stawią się we właściwym czasie w celu wejścia na pokład drugiego lotu".

Wyrok ten został wydany $w$ następujących okolicznościach sprawy. G. Rodríguez Cachafeiro oraz M. Martínez-Reboredo Varela-Villamor zakupili od Iberii bilet lotniczy na trasie A Coruña (Hiszpania) - Santo Domingo. Bilet ten obejmował dwa loty: lot IB 513, A Coruña - Madryt 4 grudnia $2009 \mathrm{r}$. (w godzinach 13.30-14.40), oraz lot IB 6501, Madryt - Santo Domingo w tym samym dniu (w godzinach 16.05-19.55). Na stanowisku odprawy biletowobagażowej Iberii na lotnisku w A Coruña powodowie odprawili swoje bagaże bezpośrednio do końcowego miejsca przeznaczenia i każdemu z nich wydane zostały dwie karty pokładowe odpowiadające kolejnym dwóm lotom. Pierwszy z lotów był opóźniony (godzinę i dwadzieścia pięć minut). Zakładając, że opóźnienie to doprowadzi do spóźnienia się pasażerów na ich lot łączony w Madrycie, Iberia o godzinie 15.17 anulowała ich karty pokładowe na drugi lot przewidziany na godzinę 16.05 . Po przybyciu powodów do Madrytu stawili się oni przy wskazanej bramie wejścia na pokład w chwili, w której przedsiębiorstwo lotnicze po raz ostatni wzywało pasażerów. Pracownicy Iberii odmówili im jednak wejścia na pokład z tego powodu, że ich karty pokładowe zostały anulowane, a ich miejsca przydzielone innym pasażerom. Powodowie dotarli innym lotem do końcowego miejsca przeznaczenia $\mathrm{z}$ dwudziestosiedmiogodzinnym opóźnieniem. W związku z tym powodowie zwrócili się do sądu o nakazanie Iberii wypłaty dla każdego z nich z osobna odszkodowania w kwocie 600 euro z tytułu ,odmowy przyjęcia na pokład”. Iberia nie zgodziła się z tymi roszczeniami, podnosząc, że okoliczności, na podstawie których wniesiono pozew do tego sądu, nie stanowiły „odmowy przyjęcia na pokład”, lecz powinny 
być oceniane jako spóźnienie na połączenie z lotem, ponieważ decyzja o odmowie przyjęcia powodów na pokład nie może zostać przypisana nadmiernej rezerwacji (overbooking), lecz była uzasadniona opóźnieniem wcześniejszego lotu. Sąd Juzgado de lo Mercantil $\mathrm{n}^{\circ} 2$ de A Coruña, nie mając pewności co do pojęcia „odmowy przyjęcia na pokład”, postanowił zawiesić postępowanie i zwrócić się do Trybunału z następującym pytaniem prejudycjalnym: „Czy przypadek, kiedy przewoźnik lotniczy odmawia przyjęcia na pokład z tego powodu, iż pierwszy etap podróży wskazany na bilecie doznał opóźnienia, za które przewoźnikowi temu można przypisać winę, i błędnie założył on, iż pasażerowie nie przybęda o czasie na drugi lot, co pozwala na to, aby ich miejsca zostały zajęte przez innych pasażerów, można uznać za objęty pojęciem »odmowa przyjęcia na pokład « w rozumieniu art. 2 lit. j) w związku z art. 3 ust. 2 i art. 4 ust. 3 [rozporządzenia $\mathrm{nr} 261 / 2004]$ ?".

Trybunał stwierdził, że pojęcie „odmowy przyjęcia na pokład” obejmuje sytuację, gdy w ramach umowy jednego transportu obejmującego kilka rezerwacji na bezpośrednio następujące po sobie loty, na które odprawa dokonywana jest jednocześnie, przewoźnik lotniczy odmawia przyjęcia na pokład niektórych pasażerów z tego powodu, iż pierwszy lot objęty rezerwacją był opóźniony, a za opóźnienie to winę ponosi ów przewoźnik błędnie przewidujący, że pasażerowie ci nie stawią się we właściwym czasie w celu wejścia na pokład drugiego lotu.

Należy zgodzić się ze stwierdzeniem TSUE. Po pierwsze, zgodnie z wykładnią celowościową przepis rozporządzenia musi być tłumaczony tak, aby był najbardziej zdatnym środkiem do osiagnnięcia celu, jaki przyświecał wydaniu rozporządzenia. Ustawodawca, uzupełniając luki prawne rozporządzenia nr 295/91, miał na celu zredukowanie nadmiernej liczby pasażerów, którym odmówiono przyjęcia na pokład wbrew ich woli. Jak słusznie zauważa Trybunał - to $\mathrm{w}$ tym kontekście prawodawca art. 2 lit. j) rozporządzenia nr 261/2004 zniósł w definicji pojęcia „odmowy przyjęcia na pokład” każde odniesienie do powodu, dla którego dany przewoźnik odmawia przewozu pasażera ${ }^{19}$. Takie zamierzone posunięcie rozciągnęło zakres rzeczonej definicji poza sam tylko przypadek odmowy przyjęcia na pokład z powodu nadmiernej rezerwacji przewidzianego wcześniej w art. 1 rozporządzenia nr 295/91 i przyznało jej szerokie znaczenie obejmujące sytuacje, w których przewoźnik lotniczy odmawia przewozu pasażerów. Ponadto - jak zauważa TSUE w wielu wyrokach $^{20}$ - uzasadnienia szerokiej wykładni praw przyznanych pasażerom możemy szukać w zagwarantowaniu wysokiego poziomu ochrony pasażerów.

Trybunał wielokrotnie podkreślał, że każdy budzący wątpliwości znaczeniowe przepis powinien być rozważany we właściwym kontekście i interpretowany $\mathrm{w}$ świetle całokształtu przepisów ${ }^{21}$. Wykładania funkcjonalna zmusza nas do tego, byśmy, interpretując przepis prawny, uwzględniali jego funkcję. Przepisy regulujące kwestie odmowy wpuszczenia na pokład mają służyć

\footnotetext{
${ }^{19}$ Wyrok z 4 października 2012 r. w sprawie C-321/11, pkt 23.

${ }^{20}$ Wyroki: z 10 stycznia 2006 r. w sprawie C344/04, IATA $i$ ELFAA, Zb. Orz., s. I-403, pkt 69; a także z 22 grudnia 2008 r. w sprawie C549/07, Wallentin-Hermann, Zb. Orz., s. I-11061, pkt 18 cyt w: wyroku z 4 października 2012 r. w sprawie C-321/11, pkt 25.

${ }^{21}$ A. Kalisz, Wyktadnia..., s. 161. Zob. cytowane tam liczne wyroki Trybunału.
} 
zredukowaniu nadmiernej liczby pasażerów, którym odmówiono przyjęcia na pokład wbrew ich woli. Przy interpretacji należy ponadto brać pod uwagę zasady sprawiedliwości i słuszności i wybrać taką interpretację, która będzie najkorzystniejsza. Wobec tego zgodzenie się ze stwierdzeniem, że przepisy dotyczą wyłącznie sytuacji zawyżonej liczby rezerwacji na dany lot, prowadziłoby do narażania pasażerów na poważne trudności i niedogodności związane z odmową przyjęcia na pokład nawet wówczas, gdy winę ponosi sam przewoźnik (np. za opóźnienie pierwszego wykonywanego przez niego lotu bądź gdy błędnie stwierdził, że pasażerowie nie będą w stanie stawić się na czas u wejścia na pokład kolejnego lotu, bądź też gdy sprzedał bilety na kolejne loty, w stosunku do których błędnie założył, że pasażerowie na nie nie zdążą).

\section{UWAGI KOŃCOWE}

Interpretacja przepisów dotyczących odmowy przyjęcia na pokład przez Trybunał Sprawiedliwości Unii Europejskiej oraz przez Wojewódzki Sąd Administracyjny w Warszawie jest całkowicie odmienna. Wyraźnie widać, że Trybunał jest „luźniej” związany literą prawa, WSA w Warszawie dał natomiast bezwzględne pierwszeństwo argumentacji językowej. Prawo europejskie stanowi autonomiczny porządek prawny. Ten autonomiczny charakter wpływa z kolei na reguły dotyczące stosowania prawa. Proces wykładni natomiast uzależniony jest niejako od określonego systemu dyrektyw interpretacyjnych $^{22}$.

W polskiej kulturze prawnej nie budzi wątpliwości fakt, że zastosowanie językowych dyrektyw wykładni stanowi konieczny element wykładni. Czy jednak przy stosowaniu prawa europejskiego, zasada ta dalej obowiązuje w sposób bezwzględny i czy wobec tego wykładnia pozajęzykowa, a w szczególności wykładnia funkcjonalna, nie jest już traktowana jako konieczny element wykładni? W orzecznictwie sądów krajowych znajdujemy różne poglądy w kwestii konieczności dokonywania wykładni pozajęzykowej, ,jednak przewagę wydaje się mieć postawa polegająca na przeprowadzaniu wykładni pozajęzykowej nawet w wypadku jednoznacznych wyników wykładni językowej" ${ }^{23}$. A skoro odchodzi się już niejako od ścisłego związania litera prawa przy stosowaniu prawa krajowego, tym bardziej należałoby to uczynić, stosując

${ }^{22}$ Zob. J. Barcz (red.), Prawo Unii Europejskiej. Zagadnienia systemowe, Warszawa 2006; S. Biernat, Wyktadnia prawa krajowego w zgodzie z prawem Wspólnoty Europejskiej, w: C. Mik (red.), Implementacja prawa integracji europejskiej krajowych porzadkach prawnych, Toruń 1998, s. 130; M. Etel, Pojęcie przedsiębiorcy $w$ prawie polskim i prawie Unii Europejskiej oraz $w$ orzecznictwie sadowym, Warszawa 2012, s. 67; C. Mik, Wyktadnia prawa Unii Europejskiej, Toruń 2008, s. 9; idem, Europejskie prawo wspólnotowe. Zagadnienia teorii $i$ praktyki, t. 1, Warszawa 2000, s. 684 i n.; A. Wróbel, Zgodna $z$ dyrektywami WE/UE sadowa wyktadnia prawa państw cztonkowskich WE/UE. Zarys problemu, w: L. Gardocki et al. (red.), Orzecznictwo sadowe $w$ sprawach karnych. Aspekty europejskie $i$ unijne, Warszawa 2008, s. 51-70.

${ }^{23}$ O. Bogucki, Problem zakończenia procesu wyktadni prawa w świetle orzecznictwa Sadu Najwyższego, w: O. Nawrot, S. Sykuna, J. Zajadło (red.), Konwergencja czy dywergencja kultur i systemów prawnych?, Warszawa 2012, s. 158. 
prawo europejskie, które jest „wypadkową różnorodnych interesów państw członkowskich i różnych grup nacisku oraz rezultatem działania licznych organów prawotwórczych WE" ${ }^{24}$. Wykładnia językowa prawa europejskiego powinna więc być jedynie punktem wyjścia ustaleń derywacyjno-klaryfikacyjnych $^{25}$. Ponadto istnieje tendencja do dokonywania tzw. wykładni łącznej, która kompiluje ponadnarodowe i krajowe argumenty interpretacyjne ${ }^{26}$.

W związku z tym oraz mając na względzie dwa podstawowe cele: zredukowania nadmiernej liczby pasażerów, którym odmówiono przyjęcia na pokład wbrew ich woli, a także zagwarantowania wysokiego poziomu ochrony pasażerów, należy stwierdzić, że definicja „odmowy przyjęcia na pokład” powinna być szersza niż sam tylko wypadek odmowy przyjęcia na pokład $\mathrm{z}$ powodu nadmiernej rezerwacji. Takiej definicji należy przyznać szerokie znaczenie obejmujące sytuacje, w których przewoźnik lotniczy odmawia przewozu pasażerów, a zwłaszcza gdy winę ponosi sam przewoźnik, np. za opóźnienie pierwszego wykonywanego przez niego lotu, bądź gdy błędnie stwierdził, że pasażerowie nie będą w stanie stawić się na czas u wejścia na pokład kolejnego lotu, bądź też gdy dokonał sprzedaży biletów na kolejne loty, w stosunku do których błędnie założył, że pasażerowie na nie nie zdążą.

Obecnie jesteśmy świadkami toczących się prac nad zmianą rozporządzenia. Komisja Europejska wszczęła proces konsultacji społecznych dotyczących ewentualnych zmian rozporządzenia nr 261/2004. Do 11 marca 2012 r. zainteresowani mogli zgłaszać swoje uwagi za pośrednictwem strony internetowej, wypełniając online questionnaire ${ }^{27}$. 13 marca 2013 r. Komisja Europejska przedstawiła projekt rozporządzenia Parlamentu Europejskiego i Rady zmieniającego rozporządzenie (WE) nr 261/2004 ustanawiającego wspólne zasady odszkodowania i pomocy dla pasażerów w wypadku odmowy przyjęcia na pokład albo odwołania lub dużego opóźnienia lotów oraz rozporządzenie (WE) nr 2027/97 w sprawie odpowiedzialności przewoźnika lotniczego w odniesieniu do przewozu drogą powietrzną pasażerów i ich bagażu ${ }^{28}$.

Preambuła odwołuje się do wyroku w sprawie C-22/11 (Finnair), w której TSUE stwierdził, że pojęcie ,odmowa przyjęcia na pokład” powinno być interpretowane w ten sposób, że obejmuje ono nie tylko odmowę przyjęcia na pokład wynikającą z nadmiernej rezerwacji, lecz również odmowę przyjęcia na pokład z innych powodów, takich jak przyczyny operacyjne. Biorąc pod uwagę to potwierdzenie, stwierdza się, iż nie ma powodu, aby zmieniać obecną definicję „odmowy przyjęcia na pokład” ${ }^{29}$. Aby podnieść poziom ochrony, pasażerom nie powinno się odmawiać wejścia na pokład w celu odbycia podróży powrotnej na podstawie biletu powrotnego w sytuacjach, gdy nie odbyli oni podróży do miejsca przeznaczenia ${ }^{30}$. Pasażerom, którzy nie zdążyli na lot łączony, należy

24 A. Kalisz, Wyktadnia..., s. 153.

${ }^{25}$ Ibidem, s. 155.

${ }^{26}$ A. Kalisz, Interpretacja..., s. 365.

${ }^{27}$ Kwestionariusz dostępny był na: http://ec.europa.eu/transport/passengers/consultations/ 2012-03-11-apr_en.htm.

${ }^{28}$ Bruksela, 13.3.2013 COM(2013) 130 final, 2013/0072 (COD).

${ }^{29}$ Preambuła, pkt 6.

${ }^{30}$ Preambuła, pkt 7. 
zapewnić odpowiednią opiekę na czas, w którym dokonuje się zmiany planu podróży. Zgodnie z zasadą równego traktowania tacy pasażerowie powinni mieć możliwość ubiegania się o odszkodowanie na podobnej zasadzie, jak pasażerowie, których loty zostały opóźnione lub odwołane, ze względu na opóźnienie w chwili osiagnnięcia ostatecznego celu podróży ${ }^{31}$.

Według art. 6a w wypadku, gdy pasażer utraci możliwość skorzystania z lotu łączonego wskutek opóźnienia lub zmiany rozkładu w odniesieniu do poprzedniego lotu, unijny przewoźnik lotniczy obsługujący kolejny lot łączony zapewnia pasażerowi pomoc i zmianę planu podróży. W wypadku gdy pasażer utraci możliwość skorzystania z lotu łączonego w wyniku opóźnienia wcześniejszego lotu łączonego, pasażerowi przysługuje prawo do odszkodowania ze strony unijnego przewoźnika lotniczego obsługującego taki wcześniejszy lot.

Ustawodawca proponuje więc, by definicja ,odmowy przyjęcia na pokład” była szersza niż sam tylko wypadek odmowy przyjęcia na pokład z powodu nadmiernej rezerwacji, dodatkowo regulując sytuację tzw. lotu łączonego ${ }^{32}$.

W praktyce wielu pasażerów nie pojawia się na lot z różnych powodów: opóźnień tranzytowych, choroby, zaspania, zmiany planów itp. Przewoźnicy lotniczy krajów rozwiniętych zazwyczaj sprzedają o około $2 \%$ więcej biletów niż miejsc, podczas gdy linie lotnicze z rozwijających się krajów nawet o $5 \%$. Przykładowo na samolot typu Airbus 380 (posiadający 555 miejsc w 3-klasowej konfiguracji) przewoźnik będzie sprzedawać do 583 biletów, a wobec tego prawie 30 osobom może zostać odmówiony przelot. Jest to dozwolona praktyka przewoźników lotniczych wynikająca z ich ochrony właśnie przed tzw. no-shows.

dr Anna Konert

Uczelnia Łazarskiego $w$ Warszawie

a.konert@lazarski.edu.pl

\title{
DENIED AIRCRAFT BOARDING UNDER REGULATION (EC) NO 261/2004
}

\author{
Summary
}

The paper analyses overbooking and denied boarding in air transportation under Regulation (EC) No 261/2004 of the European Parliament and of the Council of 11 February 2004 establishing common rules on compensation and assistance to passengers in the event of denied boarding and cancellation or long delay of flights, and repealing Regulation (EEC) No 295/91. Overbooking is a situation when airlines sell more tickets for a scheduled flight than there are seats on the aircraft. This issue is analysed based on two different judgments: one of the Polish court (Wojewódzki Sąd Administracyjny) and the other of the Court of Justice of the European Union.

\footnotetext{
31 Preambuła, pkt 13.

32 „Lot łączony” oznacza lot, który na podstawie jednej umowy przewozu ma umożliwić pasażerowi przybycie do punktu przesiadkowego w celu odbycia kolejnego lotu albo - jeśli tak wynika z kontekstu taki inny lot odbywający się z punktu przesiadkowego (art. 1 ust $1 \mathrm{e}$ ).
} 
Copyright of Journal of Law, Economics and Sociology is the property of Faculty of Law and Administration of Adam Mickiewicz University in Poznan and its content may not be copied or emailed to multiple sites or posted to a listserv without the copyright holder's express written permission. However, users may print, download, or email articles for individual use.

Właścicielem praw autorskich do „Ruchu Prawniczego, Ekonomicznego i Socjologicznego” jest Wydział Prawa i Administracji Uniwersytetu im. Adama Mickiewicza w Poznaniu. Zawartość czasopisma nie może być kopiowana, przesyłana do innych stron internetowych bądź zamieszczana na blogach bez pisemnej zgody wydawcy. Niemniej artykuły można drukować, kopiować lub przesyłać w formie elektronicznej na własny użytek. 